\title{
The Impact of Indian Dramas on Language and Dressing of Females
}

\author{
Arshad Ali, Ammarah Khalid and Syed Ali Hassan*
}

Centre for Media and Communication Studies, University of Gujrat, Post code 50700 Gujrat, Punjab, Pakistan

\begin{abstract}
This study investigates the "Impact of Indian dramas on language and dressing of females of village Sehowal district Sialkot" through survey using a questionnaire as a tool of data collection. It targeted 100 women aged 1630 years and viewing cable television for a minimum two years. The study recorded the respondent's consumption patterns, level of viewing, preferred channels, favorite watching time, and control over remote. It checked the above factors with the age group and marital status with demographic characteristics of the respondents. Results show that Indian media trying to cultivate their culture in our society, females even in the village area like Indian dresses and use Hindi words Intentionally or unintentionally but there is the slight changes occur in Interaction pattern.
\end{abstract}

Keywords: Females; Indian dramas; Language; Dressing; Interaction; Cultivation; Impact of dramas

\section{Introduction}

Media is playing very important role in our society, due to alien media; Pakistani society is in danger zone. Cable television viewership is no more restricted to the upper-middle class only; with the availability of low-priced television and cable connection, it has become a common household facility for the lower class as well. Viewers have access to a variety of channels from local to foreign, which provide them an opportunity to watch all types of programmers. Zia [1] stated that the reasons for this rapid growth of cable television to include easy access, low cost, access to satellite channels and a huge television viewer-ship interested in entertainment only. The Muslims were highly affected by the Hindu's culture because of living with them together for a longer period in Sub-Continent. In this way, now we are facing cultural conflict and identity crisis at a large scale [2]. Culture or civilization is a complex whole which includes knowledge, belief, art, law, customs and other capabilities and habits acquired by man as a member of society [3]. People like Indian films, dramas and even ads and they learn a lot of things from the foreign media. Culture is a backbone of any society; it is the identification of a nation. Satellite transmission is putting a great influence on Pakistani society, but after the cable transmission the power of influence is increasing. Pakistan is a Muslim country and Pakistani culture is the unique pattern of belief, ideas, values highly influenced by the religion of Islam. Islam in Pakistan sets the code of ethics in the cultural life for the people of Pakistan. But People gained western and Indian culture due to acculturations modernization and westernization. Pakistan has an impact of Indian dressing culture as well. Now, people like to wear Sarhi, Patiala Shalwar, Chori Pajama, sleeveless dress, short shirts and less use of chadar (veil) etc [4].

In Pakistan, our drama industry made a sudden impact on minds of peoples. Our Pakistani drama channels such as Indus Vision, ARY digital, Hum TV and Geo entertainment, etc., Are highly influenced by Indian and western channels and trying to compete with these channels to serve as the translator for our society. They are losing its cultural identity by showing off, glamour, romance, etc. The Indian dramas \&films have frequent and intensive negative impact on our social, cultural, religious beliefs and values of Pakistani youth. We all are accepting it. The effects are clearly visible on lifestyles, food, dressing, language, traditional celebrations and religion. When we look around us, find fashion everywhere, girls or boys wearing fashionable clothes, sitting together, full makeup, stylish haircuts etc. Teenagers are fond of burgers, coke and hotling thus; we can say that the media is now introducing new trends, behaviors, attitudes and standards for a modern life which greatly affected the society. Today media play an important role in the promotion of Hindi language in Pakistan. Because people, mostly watch Indian programs and they adopt many Hindi words. They use Hindi words in daily routine e.g. didi (sister) "jeej" (brother in law) "shanty" (sakoon) "vishwas" (trust) "pati" (husband). Indian television shows have contributed heavily to the Sanskritisation of Urdu in Pakistan, and it has been reported that many Hindi words such as Namaste, maharani and chinta, which have been an inherent part of Sanskritized Hindi, have entered standard usage in Pakistan due to the influence of these soaps and Bollywood movies and Indian dramas. Media present the modernization and westernization and it has a negative impact on the original culture, gifted by Islam, but we are not denying the bad effects of the Indian style of dressing that we have adapted. The examples are wearing off Sarhi, Sleeveless, dressing, short shirts, less use of cheddars, etc.... On special occasions ladies use to wear Indian culture to show off. People have learned these things through Indian dramas and movies. Therefore, objectives of this study are following.

- To explore how viewing the Indian dramas affect the viewers.

- To check either the Indian media trying to cultivate their culture in our society.

- To check, how much Indian dramas lead to adoption of Indian language.

- To check, how much Indian dramas lead to adoption of Indian dresses.

\section{Hypothesis}

- Greater the exposure to cable television greater the effect on the language and dressing of females in village Sehowal, district Sialkot.

*Corresponding author: Syed Ali Hassan, Centre for Media and Communication Studies, University of Gujrat, Post code 50700 Gujrat, Punjab, Pakistan, Tel: 0792630 1341; E-mail: peacemind.world@gmail.com

Received January 29, 2014; Accepted March 27, 2014; Published April 02, 2014

Citation: Ali A, Khalid A, Hassan SA (2014) The Impact of Indian Dramas on Language and Dressing of Females. J Mass Communicat Journalism 4: 186. doi:10.4172/2165-7912.1000186

Copyright: @ 2014 Ali A, et al. This is an open-access article distributed under the terms of the Creative Commons Attribution License, which permits unrestricted use, distribution, and reproduction in any medium, provided the original author and source are credited. 
- There is no impact of Indian dramas on language and dressing of females of village Sehowal district Sialkot.

- Most of the Starplus viewers use Hindi words in their daily life.

- Indian dressing is the most influencing variable in Pakistani society.

\section{Literature Review}

The focal point of this study is to evaluate the effects of on women's life patterns in respect of language and dressing style in village Sehowal. Joshi [5] has surveyed the participation of women in decision making at Indian television (Door Darshan). A survey of women viewers in Madras city indicates the superficiality of women's programs. But my study focuses on the impact of Indian dramas on females regarding the dressing and language [6]. A study conducted by Saleem [7] "Cultural Imperialism: A case study of the impact of dish antenna on Pakistani society" concluded that dish antenna's programmers are successfully influencing the socio-cultural and religious beliefs and values of Pakistani viewers. An alarming issue came to light that projection of other cultures and values has compelled 36 percent respondents from all to think that Islam is a conservative religion and they appreciated socioeconomic and religious values of western societies.

A survey conducted by Rahim [8,9] indicated the change in the lifestyle of women in Hyderabad. He reports the changes in the behavior of typical housewives in many ways. The interaction with husband and children rejoiced. Time spend in socialism also decreased. Cooking pattern changed, resulting in the introduction of new dishes. Dress, outlook and appearance were disturbed along with language. The effect of dish antenna on PTV dramas by Noreen Shafiq [10] concluded that the number of private satellite channels was increasing. PTV was not producing new and interesting programmers, for the public. The standard of programmers was falling. With the arrival of dish antenna people liked to watch Zee TV and enjoyed BBC. Now there were ten channels in Urdu language at the same time, so one could judge the position of PTV. Shahbaz [11] emphasizes on the influence or impact of daily night transmission of Star Plus family dramas on social and cultural values and norms of Pakistani youth of the middle class. The survey research concludes that the social-cultural thinking of Pakistani youth is under the foreign cultural values through these Star Plus dramas. They are also affecting the language, fashion, food and architect, social behavior and daily life style of Pakistani society. These dramas have increased the generation gap. And through these dramas, Pakistani youths have become more money oriented. They have created an impact on the 'lifestyle' of middle class Pakistani youth and influenced the thoughts of modernist and traditionalist thinkers. Star plus is actually interred mingling the eastern and western culture resulting in the formation of an 'International Culture' and promoting more liberalism and modernism in Pakistani society and youth. They have an impact on social interactions and on norms and values of youngsters and have increased the desires, demands and idealism in Pakistani youth. These Star Plus dramas have frequent and intensive negative impact of Pakistani youth's social and cultural norms and values. The Cultivation Theory asserts that heavy viewers' attitudes are cultivated primarily by what they watch on television. Gerbner views this television world as "not a window on or a reflection of the world, but a world in itself" [12]. Cultivation Theory, in its most basic form, suggests that television is responsible for shaping or 'cultivating' viewers' conceptions of social reality. The combined effect of massive television exposure by viewers over time subtly shapes the perception of social reality for individuals and, ultimately, for our culture as a whole.
Thus, cultivation research is in the effects tradition. Cultivation theorists argue that television has long-term effects which are small, gradual, indirect but cumulative and significant. Nonetheless, the Gerbner's work presents a Social Psychology Theory on communication effect on persuasion as related mass media. $\mathrm{He}$ argues that the mass media cultivate attitudes and values which are already present in the culture. Media maintains and propagates these values amongst members of a culture, thus binding it together. The Cultivation Theory got its start with the cultivation hypothesis, created by George Gerbner, which attempts to understand how "heavy exposure to cultural imagery will shape a viewer's concept of reality" [13].

\section{Methodology}

Researchers used a survey method to investigate the impact of Indian dramas on language and dressing of females. The target population is the females of village Sehowal and 100 sample sizes are taken to investigate this study. Cluster sampling was used in the research in which researchers defined different groups of female according to age. The age groups are 16 to 20,21 to 24 and from 24 to 30 . The unit of analysis of the present study is females of different age groups. Researchers measured the effect of Indian dramas on language and dressing.

\section{Analysis}

Table 1 shows that $60 \%$ Respondents like to watch cable television along with someone between them $7 \%$ belongs to 16-20 age groups, $22 \%$ belong to $21-24$ age groups and $11 \%$ belongs to $26-30$ age groups. $38 \%$ Respondent like to watch cable television along between them $17 \%$ belongs to $16-20$ age groups, $15 \%$ belong to $21-24$ age groups and $6 \%$ belong to $25-30$ age groups. Table 2 shows that $32 \%$ Respondents have a cable connection at their home from one year between them $14 \%$

\begin{tabular}{|c|c|c|c|c|c|c|}
\hline & & & \multicolumn{3}{|c|}{ Age } & \multirow[t]{2}{*}{ Total } \\
\hline & & & $16-20$ & $21-24$ & $25-30$ & \\
\hline \multirow{4}{*}{$\begin{array}{l}\text { Do you like to } \\
\text { watch cable } \\
\text { television? }\end{array}$} & Alone & Count & 17 & 15 & 6 & 38 \\
\hline & & $\%$ of Total & $17.0 \%$ & $15.0 \%$ & $6.0 \%$ & $38.0 \%$ \\
\hline & $\begin{array}{l}\text { Along with } \\
\text { someone }\end{array}$ & Count & 27 & 22 & 11 & 60 \\
\hline & & $\%$ of Total & $27.0 \%$ & $22.0 \%$ & $11.0 \%$ & $60.0 \%$ \\
\hline \multirow[t]{2}{*}{ Total } & & Count & 45 & 38 & 17 & 100 \\
\hline & & Total $\%$ of & $45.0 \%$ & $38.0 \%$ & $17.0 \%$ & $100.0 \%$ \\
\hline
\end{tabular}

Table 1: Do you like to watch cable television?

\begin{tabular}{|c|c|c|c|c|c|c|}
\hline & & & \multicolumn{3}{|c|}{ Age } & \multirow[t]{2}{*}{ Total } \\
\hline & & & $16-20$ & $21-24$ & $25-30$ & \\
\hline \multirow{8}{*}{$\begin{array}{l}\text { Since when do } \\
\text { you have a cable } \\
\text { connection at } \\
\text { home? }\end{array}$} & 1 year & Count & 14 & 13 & 5 & 32 \\
\hline & & $\%$ of Total & $14.0 \%$ & $13.0 \%$ & $5.0 \%$ & $32.0 \%$ \\
\hline & 2 years & Count & 10 & 7 & 5 & 22 \\
\hline & & $\%$ of Total & $10.0 \%$ & $7.0 \%$ & $5.0 \%$ & $22.0 \%$ \\
\hline & 3 years & Count & 12 & 7 & 4 & 23 \\
\hline & & $\%$ of Total & $12.0 \%$ & $7.0 \%$ & $4.0 \%$ & $23.0 \%$ \\
\hline & $\begin{array}{l}\text { More than } \\
3 \text { years }\end{array}$ & Count & 9 & 11 & 3 & 23 \\
\hline & & $\%$ of Total & $9.0 \%$ & $11.0 \%$ & $3.0 \%$ & $23.0 \%$ \\
\hline \multirow[t]{2}{*}{ Total } & & Count & 45 & 38 & 17 & 100 \\
\hline & & $\%$ of Total & $45.0 \%$ & $38.0 \%$ & $17.0 \%$ & $100.0 \%$ \\
\hline
\end{tabular}

Table 2: Since when do you have a cable connection at home? 
Citation: Ali A, Khalid A, Hassan SA (2014) The Impact of Indian Dramas on Language and Dressing of Females. J Mass Communicat Journalism 4: 186. doi:10.4172/2165-7912.1000186

Page 3 of 5

\begin{tabular}{|c|c|c|c|c|c|c|}
\hline & & & \multicolumn{3}{|c|}{ Age } & \multirow[t]{2}{*}{ Total } \\
\hline & & & $16-20$ & $21-24$ & $25-30$ & \\
\hline \multirow{6}{*}{$\begin{array}{l}\text { How many } \\
\text { hours you } \\
\text { daily watch } \\
\text { cable } \\
\text { television? }\end{array}$} & $\begin{array}{l}1 \text { to } 2 \\
\text { hours }\end{array}$ & Count & 19 & 15 & 8 & 42 \\
\hline & & $\%$ of Total & $19.0 \%$ & $15.0 \%$ & $8.0 \%$ & $42.0 \%$ \\
\hline & $\begin{array}{l}2 \text { to } 4 \\
\text { hours }\end{array}$ & Count & 12 & 12 & 4 & 28 \\
\hline & & $\%$ of Total & $12.0 \%$ & $12.0 \%$ & $4.0 \%$ & $28.0 \%$ \\
\hline & $\begin{array}{l}\text { More than } \\
4 \text { hours }\end{array}$ & Count & 14 & 11 & 4 & 29 \\
\hline & & $\%$ of Total & $14.0 \%$ & $11.0 \%$ & $4.0 \%$ & $29.0 \%$ \\
\hline \multirow[t]{2}{*}{ Total } & & Count & 45 & 38 & 17 & 100 \\
\hline & & $\%$ of Total & $45.0 \%$ & $38.0 \%$ & $17.0 \%$ & $100.0 \%$ \\
\hline
\end{tabular}

Table 3: How many hours you daily watch cable television?

\begin{tabular}{|c|c|c|c|c|c|c|}
\hline & & & \multicolumn{3}{|c|}{ Age } & \multirow[t]{2}{*}{ Total } \\
\hline & & & $16-20$ & $21-24$ & $25-30$ & \\
\hline \multirow{8}{*}{$\begin{array}{l}\text { Which cable } \\
\text { television } \\
\text { channel do } \\
\text { you usually } \\
\text { watch? }\end{array}$} & star plus & Count & 19 & 17 & 14 & 50 \\
\hline & & $\%$ of Total & $19.0 \%$ & $17.0 \%$ & $14.0 \%$ & $50.0 \%$ \\
\hline & Colors & Count & 6 & 5 & 0 & 11 \\
\hline & & $\%$ of Total & $6.0 \%$ & $5.0 \%$ & $0 \%$ & $11.0 \%$ \\
\hline & zee TV & Count & 16 & 15 & 3 & 34 \\
\hline & & $\%$ of Total & $16.0 \%$ & $15.0 \%$ & $3.0 \%$ & $34.0 \%$ \\
\hline & Life ok & Count & 4 & 1 & 0 & 5 \\
\hline & & $\%$ of Total & $4.0 \%$ & $1.0 \%$ & $0 \%$ & $5.0 \%$ \\
\hline \multirow[t]{2}{*}{ Total } & & Count & 45 & 38 & 17 & 100 \\
\hline & & $\%$ of Total & $45.0 \%$ & $38.0 \%$ & $17.0 \%$ & $100.0 \%$ \\
\hline
\end{tabular}

Table 4: Which cable television channel do you usually watch?

belongs to $16-20$ age group, $13 \%$ belongs to $21-24$ age group, and $5 \%$ belongs to 25-30 age group. 23\% Respondents have cable connection at their home from 3 and more than 3 year between them $12 \%$ belongs to 16-20 age group, $7 \%$ belongs to $21-24$ age group, $4 \%$ belongs to $25-30$ age group. $22 \%$ Respondents have cable connection at their home from 2 years between them $10 \%$ belongs to $16-20$ age group, $7 \%$ belongs to $21-24$ age group, $5 \%$ belongs to $25-30$ age group. Table 3 shows that $42 \%$ Respondents watch daily cable television from 1 to 2 hours between them $19 \%$ belongs to $16-20$ age groups, $15 \%$ belongs to $21-24$ age groups, $8 \%$ belongs to $25-30$ age groups. $29 \%$ Respondents daily watch cable television more than 4 hours between them $14 \%$ belongs to $16-20$ age group, $11 \%$ belongs to $21-24$ age group, $4 \%$ belongs to 25-30 age group. 28\% Respondents daily watch cable television from 2 to 4 hours between which $12 \%$ belongs to (16-20) and (21-24) age group and $4 \%$ belong to $25-30$ age groups. Table 4 shows that $50 \%$ Respondents mostly watch Star plus between them 19\% belongs to $16-20$ age groups, $17 \%$ belongs to $21-24$ age groups and $14 \%$ belong to $25-30$ age groups. $34 \%$ Respondents watch Zee TV between them $16 \%$ belongs to $16-20$ age groups, $15 \%$ belongs to $21-24$ age group and $3 \%$ belongs to $25-30$ age groups. $11 \%$ Respondents watch colors between them $6 \%$ belongs to $16-20$ age groups, $5 \%$ belongs to $21-24$ age group and $0 \%$ belong to $25-30$ age groups. $5 \%$ Respondents watch Life ok between them $4 \%$ belongs to $16-20$ age groups, $1 \%$ belongs to 21-24 age groups and $0 \%$ belong to $25-30$ age groups. Table 5 shows that $50 \%$ Respondents are strongly agreed that Indian dramas are the best source of information on new design and fashion trends between them $22 \%$ belongs to $16-20$ age, $20 \%$ belongs to $21-24$ age group and
$8 \%$ belong to $25-30$ age groups. $21 \%$ Respondents are disagreed that Indian dramas are the best source of information on new design and fashion trends between them $9 \%$ belongs to $16-20$ age, $8 \%$ belongs to 21-24 age group and $4 \%$ belong to $25-30$ age groups. $19 \%$ Respondents are agreed between them $8 \%$ belongs to $16-20$ age, $6 \%$ belongs to $21-24$ age group and $5 \%$ belong to $25-30$ age groups. $10 \%$ Respondents are strongly disagreed between them $6 \%$ belongs to $16-20$ age, $4 \%$ belongs to 21-24 age groups. Table 6 shows that $35 \%$ Respondents are strongly disagreed to wear Indian dresses formally between them $12 \%$ belong to $16-20$ age, $14 \%$ belong to $21-24$ age and $9 \%$ belong to $25-30$ age. $24 \%$ Respondents are strongly agreed to wear Indian dresses formally between them $12 \%$ belong to $16-20$ age, $9 \%$ belong to $21-24$ age and $3 \%$ belong to $25-30$ age. $22 \%$ Respondents agreed to wear Indian dresses formally between them $11 \%$ belong to $16-20$ age, $9 \%$ belong to 21-24 age and 2\% belong to $25-30$ age. $19 \%$ Respondents are strongly disagreed to wear Indian dresses formally between them $10 \%$ belong to 16-20 age, $6 \%$ belong to $21-24$ age and $3 \%$ belong to $25-30$ age. Table 7 shows that $51 \%$ Respondent are strongly agreed that they have learned Hindi words evidently from Indian dramas among them $23 \%$ belongs to $16-20$ age group, $17 \%$ belongs to $21-24$ age groups and $11 \%$ belongs to $25-30$ age groups. $32 \%$ Respondents are agreed between them $17 \%$ belongs to $16-20$ age group, $11 \%$ belongs to $21-24$ age groups and $4 \%$

\begin{tabular}{|c|c|c|c|c|c|c|}
\hline & & & \multicolumn{3}{|c|}{ Age } & \multirow[t]{2}{*}{ Total } \\
\hline & & & $16-20$ & $21-24$ & $25-30$ & \\
\hline \multirow{8}{*}{$\begin{array}{l}\text { Do you prefer } \\
\text { Indian dramas } \\
\text { are to be the } \\
\text { best source of } \\
\text { information on } \\
\text { new designs } \\
\text { and fashion } \\
\text { trends? }\end{array}$} & Agree & Count & 8 & 6 & 5 & 19 \\
\hline & & $\%$ of Total & $8.0 \%$ & $6.0 \%$ & $5.0 \%$ & $19.0 \%$ \\
\hline & $\begin{array}{l}\text { Strongly } \\
\text { agree }\end{array}$ & Count & 22 & 20 & 8 & 50 \\
\hline & & $\%$ of Total & $22.0 \%$ & $20.0 \%$ & $8.0 \%$ & $50.0 \%$ \\
\hline & Disagree & Count & 9 & 8 & 4 & 21 \\
\hline & & $\%$ of Total & $9.0 \%$ & $8.0 \%$ & $4.0 \%$ & $21.0 \%$ \\
\hline & $\begin{array}{l}\text { Strongly } \\
\text { disagree }\end{array}$ & Count & 6 & 4 & 0 & 10 \\
\hline & & $\%$ of Total & $6.0 \%$ & $4.0 \%$ & $0 \%$ & $10.0 \%$ \\
\hline \multirow[t]{2}{*}{ Total } & & Count & 45 & 38 & 17 & 100 \\
\hline & & $\%$ of Total & $45.0 \%$ & $38.0 \%$ & $17.0 \%$ & $100.0 \%$ \\
\hline
\end{tabular}

Table 5: Do you prefer Indiandramas are to be the bestsource of information onnew designs and fashion trends?

\begin{tabular}{|c|c|c|c|c|c|c|}
\hline & & & \multicolumn{3}{|c|}{ Age } & \multirow[t]{2}{*}{ Total } \\
\hline & & & $16-20$ & $21-24$ & $25-30$ & \\
\hline \multirow{8}{*}{$\begin{array}{l}\text { I like to wear } \\
\text { Indian dress } \\
\text { formally? }\end{array}$} & Agree & Count & 11 & 9 & 2 & 22 \\
\hline & & $\%$ of Total & $11.0 \%$ & $9.0 \%$ & $2.0 \%$ & $22.0 \%$ \\
\hline & $\begin{array}{l}\text { Strongly } \\
\text { agree }\end{array}$ & Count & 12 & 9 & 3 & 24 \\
\hline & & $\%$ of Total & $12.0 \%$ & $9.0 \%$ & $3.0 \%$ & $24.0 \%$ \\
\hline & Disagree & Count & 10 & 6 & 3 & 19 \\
\hline & & $\%$ of Total & $10.0 \%$ & $6.0 \%$ & $3.0 \%$ & $19.0 \%$ \\
\hline & $\begin{array}{l}\text { Strongly } \\
\text { disagree }\end{array}$ & Count & 12 & 14 & 9 & 35 \\
\hline & & $\%$ of Total & $12.0 \%$ & $14.0 \%$ & $9.0 \%$ & $35.0 \%$ \\
\hline \multirow[t]{2}{*}{ Total } & & Count & 45 & 38 & 17 & 100 \\
\hline & & $\%$ of Total & $45.0 \%$ & $38.0 \%$ & $17.0 \%$ & $100.0 \%$ \\
\hline
\end{tabular}

Table 6: I like to wear Indian dress formally? 


\begin{tabular}{|c|c|c|c|c|c|c|}
\hline & & & \multicolumn{3}{|c|}{ Age } & \multirow[t]{2}{*}{ Total } \\
\hline & & & $16-20$ & $21-24$ & $25-30$ & \\
\hline \multirow{8}{*}{$\begin{array}{l}\text { I have learned } \\
\text { Hindi words } \\
\text { evidently } \\
\text { from Indian } \\
\text { dramas? }\end{array}$} & Agree & Count & 7 & 11 & 4 & 32 \\
\hline & & $\%$ of Total & $17.0 \%$ & $11.0 \%$ & $4.0 \%$ & $32.0 \%$ \\
\hline & $\begin{array}{l}\text { Strongly } \\
\text { agree }\end{array}$ & Count & 23 & 17 & 11 & 51 \\
\hline & & $\%$ of Total & $23.0 \%$ & $17.0 \%$ & $11.0 \%$ & $51.0 \%$ \\
\hline & Disagree & Count & 4 & 5 & 1 & 10 \\
\hline & & $\%$ of Total & $4.0 \%$ & $5.0 \%$ & $1.0 \%$ & $10.0 \%$ \\
\hline & $\begin{array}{l}\text { Strongly } \\
\text { disagree }\end{array}$ & Count & 1 & 5 & 1 & 7 \\
\hline & & $\%$ of Total & $1.0 \%$ & $5.0 \%$ & $1.0 \%$ & $7.0 \%$ \\
\hline \multirow[t]{2}{*}{ Total } & & Count & 45 & 38 & 17 & 100 \\
\hline & & $\%$ of Total & $45.0 \%$ & $38.0 \%$ & $17.0 \%$ & $100.0 \%$ \\
\hline
\end{tabular}

Table 7: I have learned Hindi words evidently from Indian dramas?

\begin{tabular}{|c|c|c|c|c|c|c|}
\hline & & & \multicolumn{3}{|l|}{ Age } & \multirow[t]{2}{*}{ Total } \\
\hline & & & $16-20$ & $21-24$ & $25-30$ & \\
\hline \multirow{8}{*}{$\begin{array}{l}\text { I use to speak } \\
\text { Hindi words } \\
\text { during my } \\
\text { conversation } \\
\text { with others } \\
\text { usually? }\end{array}$} & Agree & Count & 4 & 5 & 1 & 10 \\
\hline & & $\%$ of Total & $4.0 \%$ & $5.0 \%$ & $1.0 \%$ & $10.0 \%$ \\
\hline & $\begin{array}{l}\text { Strongly } \\
\text { agree }\end{array}$ & Count & 6 & 5 & 2 & 13 \\
\hline & & $\%$ of Total & $6.0 \%$ & $5.0 \%$ & $2.0 \%$ & $13.0 \%$ \\
\hline & Disagree & Count & 18 & 11 & 5 & 34 \\
\hline & & $\%$ of Total & $18.0 \%$ & $11.0 \%$ & $5.0 \%$ & $34.0 \%$ \\
\hline & $\begin{array}{l}\text { Strongly } \\
\text { disagree }\end{array}$ & Count & 17 & 17 & 9 & 43 \\
\hline & & $\%$ of Total & $17.0 \%$ & $17.0 \%$ & $9.0 \%$ & $43.0 \%$ \\
\hline \multirow[t]{2}{*}{ Total } & & Count & 45 & 38 & 17 & 100 \\
\hline & & $\%$ of Total & $45.0 \%$ & $38.0 \%$ & $17.0 \%$ & $100.0 \%$ \\
\hline
\end{tabular}

Table 8: I use to speak Hindi words during my conversation with others usually?

belong to 25-30 age groups. $10 \%$ Respondents are disagreed that they have not learned Hindi words evidently from Indian dramas among them $4 \%$ belongs to $16-20$ age group, $5 \%$ belongs to $21-24$ age groups and $1 \%$ belongs to $25-30$ age groups. $7 \%$ Respondents are strongly disagreed between them $1 \%$ belongs to $16-20$ age group, $5 \%$ belongs to $21-24$ age groups and $1 \%$ belong to $25-30$ age groups. Table 8 shows that $43 \%$ Respondents are strongly disagreed that they do not use to speak Hindi words during their conversation with others, usually among them $17 \%$ belongs to $16-20$ age group, $17 \%$ belongs to $21-24$ age and $9 \%$ belongs $25-30$ age. $34 \%$ Respondents are disagreed that they do not use to speak Hindi words during their conversation with others, usually among them $18 \%$ belongs to $16-20$ age group, $11 \%$ belongs to 21-24 age and 5\% belongs $25-30$ age. $13 \%$ Respondents are strongly agreed that they use to speak Hindi words during their conversation with others, usually among them $6 \%$ belongs to $16-20$ age group, $5 \%$ belongs to 21-24 age and 2\% belongs $25-30$ age. $10 \%$ Respondents are agreed between them $4 \%$ belongs to $16-20$ age group, $5 \%$ belongs to 21-24 age and $1 \%$ belongs $25-30$ age.

\section{Discussion}

H1 states that greater the exposure of cable television greater the effect on the language and dressing on the females of village Sehowal.
This hypothesis $29 \%$ proved females of age group from 16 to 20 and 21 to 24 mostly spend more than 4 hours in watching Indian dramas and the impact of these drama's languages and dressing on the females respectively. But it's $42 \%$ not proved females spend 1 to 2 hours in watching Indian dramas.

H2 states there is no impact of Indian dramas language and dressing on the females of village Sehowal this hypothesis disapproved because there is an impact of these dramas on social cultural aspects on the Pakistani society.

H3 states "That most of the star plus viewers use Hindi words in their life". H3 is proving more the $42 \%$ people use different Hindi words in their daily life some people use these words consciously and some unconsciously use to them. 51\% Respondent agreed that they learned the words of Hindi language evidently from Indian dramas.

H4 states that "Dressing is the most influencing variable in Pakistani society." H4 is disproved because $57 \%$

Respondent strongly disagreed to wear Indian dresses casually and $35 \%$ formally. $24 \%$ people said yes we are victim of star plus dressing even they know that this kind of dressing like sari and sleeveless shirts are not according to the Islam but they like to wear it proudly.

The general findings revealed that the majority respondents had cable connection at their home from one year. Majority respondent preferred to watch star plus and their favorite watching time are after 7.p.m. According to the results majority of respondent themselves have control over the remote. So we should create awareness among people about the importance of language and about the bad impacts of other language on our identification. Ali [14] and Shahbaz [11] conducted studies on the "Impact of satellite television channels on the people living in Lahore" and the "Impact of Star Plus dramas on youth in Pakistan" respectively, also emphasizes on the influence of Star Plus family dramas on social and cultural values and norms of Pakistani youth of the middle class. The survey research concludes that socialcultural thinking of Pakistani youth is under the influence of foreign cultural values. They are also affecting language, fashion, food and Architecture, social behavior and daily lifestyle of Pakistani society. The eastern and western cultures are intermingled in these dramas, resulting in an 'international culture' and promoting liberalism and modernism in Pakistani society.

\section{Conclusion}

This study explored the "impact of Indian drama's on language and dressing of females of village Sehowal district Sialkot, Pakistan." Many people use different words in their routine life the major source of their learning is Indian dramas. One thing is good that the majority of people dislike Indian dressing and avoids to wear it. But we should take steps about prevailing Indian dressing in Pakistani society and media campaign might be beneficial for it. Use Hindi words and Indian dressing is a biggest hurdle in the way of our success by and by we are going far away from our identification. The country which we got on the name of Islam today is following these kinds of un-Islamic things merging into Pakistani society. The time is passing speedily if we fail to block the way of these un-Islamic things the day is not far away when we lose our dignity. This research concluded that it is the responsibility of PEMRA that there must be broadcast those types of programs which are related to the ethics and values of our culture as well as presenting the real ideology of Pakistan. 
Citation: Ali A, Khalid A, Hassan SA (2014) The Impact of Indian Dramas on Language and Dressing of Females. J Mass Communicat Journalism 4: 186. doi:10.4172/2165-7912.1000186

\section{References}

1. Zia A (2003) Consumption of cable television, a research report published in cable television, A vision of the future. Pakistan Electronic Media Regulatory Authority Islamabad, Pakistan 56-61.

2. Murtaza G (2007) The impact of culture conflict on identity with an emphasis on Pakistan. Thesis, $(\mathrm{PhD})$. Department of social science, University of the Punjab, Lahore.

3. Lane J, Erison S (2007) Culture and politics. $2^{\text {nd }}$ Edition. England: Ashgate publishing limited 16-17.

4. Batool U (2007) What are impacts of Indian dressing in Pakistan? Society and politics.

5. Joshi PC (1985) An Indian personality for television: Report of the working group Software for Doordarshan, New Delhi: Government of India.

6. Tamakuwala SJ (2011)

7. Saleem N (1994) Impact on dish antenna on Pakistani society: a case study of Lahore 5253.

8. Master's thesis, department of mass communication, university of the Punjab, Pakistan182.
9. Rahim A (1994) Impact of cable TV on television and video viewing in Hyderabad: A survey. Media Asia: an Asian mass communication quarterly 21: $15-20$

10. Shafiq N (1995) The effect of the dish antenna on PTV dramas. Unpublished master's thesis, Department of Mass Communication, Bahauddin Zakariya University, Multan. Pakistan.

11. Shahbaz Z (2004) Impact of cable TV channels Star Plus soap operas on socia and cultural norms and values of Pakistani youth. Unpublished master's thesis, Department of Mass Communication, Lahore College for Women University Lahore123.

12. McQuail D, Windahl S (1993) Communication models for the study of mass communication. London: Longman 100.

13. Pierce, Terry, Qamar M, Asim M, Shawar D et al. (2012) An overview of the Cultivation Theory. "The Impacts Assessment of Indian Culture on Pakistani Society in Faisalabad”. International Journal of Research in Social Sciences And Humanities 1: 53-62.

14. Ali D (2001) Impact of satellite TV channels on the people living in Lahore. Master thesis, Department of Sociology, university of Punjab, Lahore. 